\title{
Beliefs, attitudes, and propensity to buy locally produced food
}

\author{
Steven Dukeshire, Renée Garbes, Chloe Kennedy, Ainslie Boudreau, Theresa Osborne
}

Nova Scotia Agricultural College, Truro, Nova Scotia, Canada

Submitted 6 October 2010 / Accepted 6 January 2011 / Published online 24 May 2011

Citation: Dukeshire, S., Garbes, R., Kennedy, C., Boudreau, A., \& Osborne, T. (2011). Beliefs, attitudes, and propensity to buy locally produced food. Journal of Agriculture, Food Systems, and Community Development., 1(3), 19-29.

http://dx.doi.org/10.5304/jafscd.2011.013.008

Copyright (C) 2011 by New Leaf Associates, Inc.

\begin{abstract}
In this study, conducted in Nova Scotia, Canada, we surveyed people at farmers' markets, agricultural fairs, and other agricultural events to investigate the views of people who would likely be trying to incorporate local food into their everyday shopping habits. Survey respondents $(N=2,316)$

Corresponding author: Steven Dukeshire, Rural Research Center, Nova Scotia Agricultural College, Department of Business and Social Sciences, 56 Rock Garden Road, P.O. Box 550, Truro, Nova Scotia, B2N 6P6 Canada; +01-902-893-6593; fax +01-902-893-6230; sdukeshire@nsac.ca

Funding for this research was provided by Agriculture and Agri-Food Canada through Agri-Futures, Nova Scotia's A.C.A.A.F. Council, and the Canadian Institutes of Health Research (funding reference number 70781).

Theresa Osborne was the executive secretary for the Women's Institutes of Nova Scotia when the research was undertaken. She received no additional money for her role in the study.
\end{abstract}

indicated strong positive beliefs, attitudes, and propensity toward buying local food. At the same time, however, they reported difficulty identifying whether food was local as well as a lack of opportunities to buy local food. The findings build upon the growing body of research surrounding the "buy local" movement in North America by providing insight into why people want to buy local and potential barriers that prevent stronger markets for local food products.

\section{Keywords}

agricultural fairs, consumer attitudes, buy local, farmers' markets, local food, Nova Scotia, survey

\section{Introduction}

As food production and distribution become increasingly industrialized and globalized, consumers are becoming more cognizant of the potentially negative consequences posed by the 
current food system. Environmental issues (Guthman, 2004), food-safety scares and distrust of the food system (de Jonge, van Trijp, Renes, \& Frewer, 2007; de Jonge, van Trijp, van der Lans, Renes, \& Frewer, 2008; de Jonge, van Trijp, Goddard, \& Frewer, 2008; Eden, Bear, \& Walker, 2008), and the ever-increasing opacity of the food production system (Nicolosi, 2006; Pollan, 2006) have left many consumers looking for alternatives to the dominant agro-industrial food paradigm (Roininen, Arvola, \& Lähteenmäki, 2006; Selfa \& Qazi, 2005). One response to the globalized food system has been a resurgence in "buying local." The buy-local alternative has started to make its way into the mainstream consumer market as people become more conscious of what they eat and, in particular, where their food comes from (Darby, Batte, Ernst, \& Roe, 2008; Roininen, et al., 2006). Although research on buying local from the consumer perspective has been relatively sparse, there is evidence to suggest that buy-local initiatives and the buy-local movement in North America and Western Europe have experienced success as shown through growing patronage at farmers' markets (Darby, et al., 2008; Hunt, 2007) and an increase in the availability of local food at supermarkets (Chambers, Lobb, Butler, Harvey, \& Traill, 2007).

While there are likely many factors influencing the choice to buy local, such as protection of the environment, perceived health benefits, and better quality and fresher products, the main underlying factor seems to be a desire to support local farmers and the local economy. People believe that buying local food is good for the economy and beneficial for rural areas (Roininen, et al., 2006), and research suggests this positive association is often a primary reason for buying local food. For example, respondents to a survey of 950 consumers from two counties in Washington state ranked helping local farmers as one of the highest and therefore most important considerations when purchasing food (Selfa \& Qazi, 2005). Similarly, respondents to a survey conducted in Oregon state indicated that the two most important reasons for buying local were to keep farmers in the area and to support the local economy (Stephenson \& Lev, 2004). Partici- pants in a qualitative study of food choices in the United Kingdom also indicated that supporting area farmers was an important consideration when choosing to buy local (Chambers, et al., 2007).

Despite the growing buy-local movement, for most people buying local food still appears to be a secondary consideration in their food purchasing decision. The Washington state survey also asked respondents to rate the importance of 14 factors that could potentially influence their food purchasing decisions. Freshness, taste, and nutritional value were rated the most important, whereas "grown locally" was rated relatively low, at eleventh of the 14 options (Selfa \& Qazi, 2005). A study by Schneider and Francis (2005) asked 207 Nebraskans to rate 12 attributes in terms of their importance in the food-purchasing decision. Similar to the previous study, respondents indicated that quality, taste, nutrition, and price were the most important factors in their buying decision. "Locally grown or produced" products were ranked eighth out of the 12 choices. The same study also found that relatively few consumers were willing to pay more for local products, and even when they did say they would pay more, the premium was small (10\% or less). These findings are made even more noteworthy when one considers that not only are consumers generally unwilling to pay a premium for local food, but they also both associate local food with higher cost (Roininen, et al., 2006; Stephenson \& Lev, 2004), and view this higher cost as a barrier to buying local food (Chambers, et al., 2007).

Unlike many studies that sample cross sections of the general public to gauge levels of interest in buying local food, our study surveyed individuals whose interests and lifestyle increased the likelihood of their buying local food on a more regular basis. Surveying individuals who may be inclined to regularly incorporate local foods into their everyday shopping helps to gain better insight into why people make the effort to buy local and identify the barriers they may face in doing so. With that in mind, the sample for this study was primarily drawn from farmers' markets and agricultural fairs — venues that may be expected to attract indivi- 
duals who have an interest in local agriculture and local food - and therefore, perhaps, stronger motivation to incorporate buying local into their lifestyle.

Given the large number of farmers' markets and agricultural fairs in Nova Scotia, they are particularly appropriate venues for data collection in this largely rural province. There are 23 annual agricultural fairs and exhibitions across Nova Scotia, with the largest drawing 40,000 people annually (Exhibition Association of Nova Scotia, 2010). The province's agricultural fairs, like most across North America, typically include the exhibition of farm livestock, such as draft horses, cattle and goats; commercial booths and art and craft exhibits; and vegetable competitions based on the uniformity, smoothness, and freshness of the produce.

Farmers' markets have been providing Nova Scotian producers with marketing venues since 1750 , when the first farmers' market was founded in the city of Halifax (Michael, 2008). Today, consistent with industry trends across North America, there are a growing number of farmers' markets across the province. In 2004, sales from Nova Scotia's farmers' markets approximated CAD14 million. Data from 2007 indicate continued upward trends based on growing attendance at Nova Scotia farmers' markets, with over 9,300 customers and 360 vendors on average per week (Michael, 2008).

The types of activities and products present at agricultural fairs and farmers' markets likely draw people interested in supporting local agriculture. Although there is very little empirical published research on the beliefs, attitudes, and values of people attending agricultural fairs, it is frequently asserted among social scientists that farmers' markets and other direct-sale arrangements embody various sets of values and ideologies among food producers and consumers, including sustainability (Kloppenberg, Lezberg, DeMaster, Stevenson, \& Hendrickson, 2000), "marketness" and "social embeddedness" (Hinrichs, 2000), and social capital (Smithers, LaMarche, \& Joseph, 2008). For instance, Smithers, et al. (2008) found that farmers' markets draw a diverse group of consumers and producers who express varying interpretations of "local," social capital, social welfare, and other concepts pertaining to food production and consumption.

With the above in mind, it would be expected that people who attend farmers' markets and agricultural fairs, while holding a wide variety of attitudes and beliefs towards local agriculture, would also have stronger motivations to incorporate buying local food into their lifestyle. Accordingly, for analysts and social scientists, these types of venues are fertile ground in which to gauge motivations and attitudes towards alternative food systems. Therefore, farmers' markets and agricultural fairs were ideal locations to conduct the Buy Local Survey and meet the study objectives to (a) better understand beliefs and attitudes toward buying local food; (b) identify barriers to buying locally produced food; and (c) gauge public perceptions pertaining to labeling and promoting local food.

\section{Methods}

The Buy Local Survey was one component of the Buy Local Challenge project. The project was developed by the Women's Institutes of Nova Scotia in 2006 as a way to educate and encourage the public, along with producers, restaurant owners, and food retailers, to think "local" and make buying local a priority when purchasing food products. The Buy Local Survey was distributed throughout Nova Scotia from June to October 2006 by members of the Women's Institute (W.I.). Distribution of surveys through the 64 W.I. chapters across Nova Scotia helped to ensure coverage of the whole province. Surveys were completed primarily at agricultural fair booths, exhibitions, and farmers' markets. Additional surveys were given out at W.I. Buy Local Challenge information sessions and through other rural-based community groups and organizations with which W.I. members were associated. Individuals 18 years and older were handed the Buy Local Survey and asked to complete and return it immediately.

There were 2,432 surveys completed, with over $95 \%$ of respondents reporting that they lived in 
Nova Scotia. Because the W.I. Buy Local Challenge was carried out solely in Nova Scotia and perceptions about buying local may differ by region (Selfa \& Qazi, 2005; Stephenson \& Lev, 2004), only the results from Nova Scotia respondents $(n=2,316)$ were included for analysis. The surveys took respondents approximately 3 to 4 minutes to complete and asked people to indicate their responses to the following:

\section{Factors Influencing Types of Food Purchased}

Respondents were asked to rate how much each of six factors (price, ease of preparation, taste, nutritional value, organic, locally grown product) influenced their food purchasing behavior, using five-point scales ranging from 1 (not at all influential) to 5 (very influential).

\section{Sources of Local Foods}

Respondents were asked to indicate whether they considered food to be local if it were produced in their community, county, province, and country. Respondents were also asked to rate how good each of seven venues (large grocery store, convenience store, outdoor farmers' market, small fruit and vegetable market, direct from farm, fast-food restaurants, family style restaurants) was as a source for local food, using five-point scales ranging from 1 (extremely poor) to 5 (extremely good).

Propensity, Beliefs, and Ability to Purchase and Attitudes Toward Promoting Locally Produced Food Respondents were asked to indicate their level of agreement with each of the following items using five-point scales ranging from 1 (strongly disagree) to 5 (strongly agree).

\section{- Propensity to buy locally produced food}

Propensity to buy local food was assessed through four items: "I like to buy food that is produced locally," "Whenever possible, I intentionally buy locally produced food," "I make it a priority to buy locally produced food," and "I consider the place of origin when buying food."
- Perceived ability to buy locally produced food Perceived ability to obtain local food was assessed through four items: "I find it easy to get locally produced foods in the summer," "I find it easy to get locally produced foods in the winter," "It is easy to know whether the food I buy is locally grown," and "I have little choice whether or not the foods I buy are locally grown."

\section{- Beliefs about locally produced food}

Beliefs toward local food were assessed through four items: "Buying locally produced food is good for the local economy," "Buying locally produced food helps the environment,"

"Buying local food means more money goes to the farmer," and "Local food is fresher than food produced farther away."

- Attitudes toward promoting locally produce food Attitudes toward promotion of local food were assessed through three items: "The government should promote buying locally grown food," "I would buy more locally produced foods in grocery stores if the foods were clearly marked with a logo," and "I would order more locally produced foods in restaurants if the menu items were clearly marked with a logo."

\section{Demographics}

Respondents were asked to indicate their sex, age, education level, province and/or state in which they lived, population of the community in which they resided, and annual household income before taxes.

\section{Results}

\section{Characteristics of Respondents}

Table 1 presents the demographic characteristics of the sample. Overall, the majority of respondents were female $(81.4 \%)$ and covered a wide age range, although younger adults were somewhat underrepresented. Two thirds of respondents had at least some college or university education. Income was fairly evenly distributed, with one third reporting an income of over CAD60,000. Almost half $(49.2 \%)$ lived in communities of under 2,000 people. 
Table 1. Characteristics of Survey Respondents

\begin{tabular}{lc}
\hline Characteristic & Percent \\
\hline Sex & \\
Female & 81.4 \\
Male & 18.6 \\
\hline Age (years) & \\
$18-30$ & 10.7 \\
$31-45$ & 20.8 \\
$46-60$ & 37.5 \\
$61-75$ & 24.0 \\
Over 75 & 7.1 \\
\hline Education Level & \\
Less than grade 12 & 10.2 \\
Completed high school & 21.9 \\
Some college or university & 24.5 \\
Completed college or university & 43.4 \\
\hline Annual Household Income (Canadian dollars) & \\
Less than $\$ 20,000$ & 13.8 \\
\$20,000-\$39,999 & 27.7 \\
\$40,000-\$59,999 & 25.8 \\
$\$ 60,000$ or over & 32.6 \\
\hline Community Size & \\
Under 500 & 27.5 \\
$500-1,999$ & 21.7 \\
$2,000-4,999$ & 15.3 \\
$5,000-9,999$ & 10.7 \\
$10,000-49,999$ & \\
50,000 or over & \\
\hline
\end{tabular}

Factors That Influence the Types of Food Purchased Respondents were asked to indicate how influential they believed each of six factors was on their food purchasing behavior. As shown in table 2, whether the product was locally grown was given the third

Table 2. Factors That Influence Types of Food Purchesed, by Rating

\begin{tabular}{lcccccc}
\hline & & \multicolumn{5}{c}{ Percent } \\
\cline { 3 - 7 } Factor & Mean & $\mathbf{1}$ & $\mathbf{2}$ & $\mathbf{3}$ & $\mathbf{4}$ & $\mathbf{5}$ \\
\hline Taste & 4.6 & 1.3 & 0.8 & 4.5 & 26.4 & 67.0 \\
Nutritional value & 4.4 & 1.5 & 2.1 & 8.3 & 32.5 & 55.7 \\
Locally grown product & 4.1 & 3.8 & 4.3 & 16.6 & 29.3 & 46.0 \\
Price & 3.6 & 3.4 & 9.9 & 34.4 & 26.2 & 26.0 \\
Ease of preparation & 3.2 & 10.4 & 15.5 & 33.3 & 26.4 & 14.4 \\
Organic & 2.8 & 21.2 & 19.0 & 28.9 & 17.5 & 13.4 \\
\hline
\end{tabular}

Responses reported on a five-point scale with $1=$ Not at all influential to $5=$ Very influential
Table 3. Geographic Area from Which Respondents Would Consider Food To Be Local

\begin{tabular}{lc}
\hline Location & Percent “Yes" \\
\hline My community & 99.9 \\
My county & 98.8 \\
My province & 91.4 \\
My country & 37.8 \\
\hline
\end{tabular}

highest rating (mean $=4.1$ out of 5$)$, ahead of price $($ mean $=3.6)$ but behind taste $($ mean $=4.6)$ and nutritional value $($ mean $=4.4)$. Over three quarters of respondents rated whether food was locally grown as either influential or very influential on their food purchasing behavior.

\section{How Far Away Is Local}

To get a better idea of what respondents perceived as local foods, they were asked to indicate whether they would consider food produced within a certain geographic area to be local. As shown in table 3 , over $90 \%$ of respondents felt that food produced in their community $(99.9 \%)$, in their county $(98.8 \%)$, or in Nova Scotia $(91.4 \%)$ constituted local food. Just over a third considered food produced in Canada as local.

\section{Perceptions of Where To Buy Local Foods}

As shown in table 4, when asked how good different food venues were for obtaining local foods, respondents gave high ratings to farmers' markets $($ mean $=4.6$ out of 5$)$, direct from farm (mean $=$ 4.6), and small fruit and vegetable markets (mean $=$ 4.4). For all three venues, over $85 \%$ of respondents gave a rating of either 4 or 5 on a five-point scale where five signified extremely good. Large grocery stores $($ mean $=$ 2.8) and family-style restaurants $($ mean $=2.6)$ were given middle ratings as sources of locally produced food, and convenience stores (mean 
$=1.9)$ and fast-food restaurants $($ mean $=1.6)$ were given relatively low ratings.

Beliefs, Attitudes, and Propensity to Buy Locally Produced Food

Propensity to buy locally produced food

Respondents tended to indicate strong agreement with the three statements associated
Table 4. Respondents' Opinions Regarding Sources of Local Foods, by Rating

\begin{tabular}{lcccccc}
\hline & & \multicolumn{5}{c}{ Percent } \\
\cline { 3 - 7 } Source & Mean & $\mathbf{1}$ & $\mathbf{2}$ & $\mathbf{3}$ & $\mathbf{4}$ & $\mathbf{5}$ \\
\hline Outdoor farmers' market & 4.6 & 0.4 & 1.4 & 5.6 & 24.1 & 68.6 \\
Direct from farm & 4.6 & 2.4 & 2.8 & 5.8 & 12.1 & 77.0 \\
$\begin{array}{l}\text { Small fruit and vegetable } \\
\quad \text { market }\end{array}$ & 4.4 & 0.5 & 1.6 & 10.2 & 32.7 & 55.0 \\
Large grocery store & 2.8 & 17.1 & 23.6 & 34.0 & 17.2 & 8.2 \\
Family style restaurants & 2.6 & 17.5 & 30.9 & 34.7 & 12.1 & 4.8 \\
Convenience store & 1.9 & 42.0 & 31.5 & 18.6 & 5.9 & 2.1 \\
Fast food restaurants & 1.6 & 59.3 & 23.9 & 13.0 & 2.5 & 1.3 \\
\hline
\end{tabular}

Responses were on a five-point scale with $1=$ Extremely poor to $5=$ Extremely good

Table 5. Beliefs, Attitudes, and Propensity Toward Buying Locally Produced Food, by Rating

\begin{tabular}{|c|c|c|c|c|c|c|}
\hline \multirow[b]{2}{*}{ Statement } & \multirow[b]{2}{*}{ Mean } & \multirow[b]{2}{*}{1} & \multirow[b]{2}{*}{2} & \multicolumn{3}{|c|}{ Percent } \\
\hline & & & & 3 & 4 & 5 \\
\hline \multicolumn{7}{|l|}{ Propensity to buy locally produced food } \\
\hline I like to buy food that is produced locally & 4.6 & 0.5 & 1.1 & 7.9 & 22.3 & 68.2 \\
\hline $\begin{array}{l}\text { Whenever possible, I intentionally buy locally produced } \\
\text { food }\end{array}$ & 4.4 & 1.0 & 2.7 & 11.7 & 26.5 & 58.1 \\
\hline I make it a priority to buy locally produced food & 4.0 & 2.4 & 6.9 & 21.7 & 30.6 & 38.4 \\
\hline I consider the place of origin when buying food & 3.9 & 3.1 & 7.3 & 22.2 & 30.5 & 36.9 \\
\hline \multicolumn{7}{|l|}{ Beliefs about locally produced food } \\
\hline $\begin{array}{l}\text { Buying locally produced food is good for the local } \\
\text { economy }\end{array}$ & 4.7 & 0.5 & 0.8 & 3.5 & 16.7 & 78.5 \\
\hline Local food is fresher than food produced farther away & 4.4 & 1.0 & 2.1 & 11.2 & 22.9 & 62.9 \\
\hline Buying locally produced food helps the environment & 4.3 & 1.3 & 4.2 & 15.9 & 24.1 & 54.6 \\
\hline Buying local food means more money goes to the farmer & 4.2 & 1.8 & 4.3 & 17.0 & 24.5 & 52.4 \\
\hline \multicolumn{7}{|l|}{ Perceived ability to buy locally produced food } \\
\hline I find it easy to get locally produced foods in the summer & 4.2 & 1.5 & 3.9 & 14.8 & 31.3 & 48.5 \\
\hline $\begin{array}{l}\text { I have little choice over whether or not the foods I buy } \\
\text { are locally grown }\end{array}$ & 2.9 & 12.2 & 19.6 & 39.9 & 18.9 & 9.4 \\
\hline It is easy to know whether the food I buy is grown locally & 2.8 & 11.1 & 26.9 & 36.3 & 17.6 & 8.1 \\
\hline I find it easy to get locally produced foods in the winter & 2.3 & 21.5 & 37.9 & 30.7 & 7.1 & 2.9 \\
\hline \multicolumn{7}{|l|}{ Attitudes toward promoting locally produced food } \\
\hline $\begin{array}{l}\text { The government should promote buying locally grown } \\
\text { food }\end{array}$ & 4.6 & 0.8 & 1.4 & 5.0 & 17.7 & 75.0 \\
\hline $\begin{array}{l}\text { I would buy more locally produced foods in grocery } \\
\text { stores if the foods were clearly marked with a logo }\end{array}$ & 4.3 & 1.4 & 2.5 & 12.8 & 28.3 & 55.0 \\
\hline $\begin{array}{l}\text { I would order more locally produced foods in restaurants } \\
\text { if the menu items were clearly marked with a logo }\end{array}$ & 4.2 & 2.3 & 3.6 & 15.6 & 29.6 & 48.9 \\
\hline
\end{tabular}

Responses were on a five-point scale with $1=$ Strongly disagree to $5=$ Strongly agree 
Table 6. Propensity to Buy Local Foods By Age

\begin{tabular}{lccccc}
\hline & \multicolumn{3}{c}{ Age } \\
\cline { 2 - 6 } Statement & $\mathbf{1 8 - 3 0}$ & $\mathbf{3 1 - 4 5}$ & $\mathbf{4 6 - 6 0}$ & $\mathbf{6 1 - 7 5}$ & Over 75 \\
\hline Degree to Which Local Influences Food Choice (/5) & 3.7 & 3.9 & 4.1 & 4.3 & 4.3 \\
Propensity to Buy Local Index (/15) & 11.7 & 12.6 & 13.2 & 13.3 & 13.4 \\
\hline
\end{tabular}

with the propensity to purchase locally produced food (table 5). That is, respondents indicated that they like to buy food that is locally produced (mean $=4.6$ out of 5), whenever possible they intentionally buy local food (mean $=4.4$ ), and they make it a priority to buy locally produced food $($ mean $=4.0)$. The three items were combined to form a propensity to buy local index (mean $=12.9$ out of 15; Cronbach's alpha $=0.87$ ). Supporting the above findings, respondents also indicated that they tend to consider the place of origin when buying food $($ mean $=3.9)$.

\section{Beliefs about locally produced food}

The four belief items pertaining to local foods were given relatively high ratings by respondents (table 5). Specifically, respondents believed that buying locally produced food is good for the local economy (mean $=4.7$ ), local food is fresher than food produced farther away (mean $=4.4$ ), buying locally produced food helps the environment (mean $=4.3$ ), and buying local food means more money goes to the farmer $($ mean $=4.2)$.

\section{Perceived ability to buy locally produced food}

Respondents felt they had only moderate control in terms of their ability to obtain locally produced food (table 5). Respondents indicated that they found it easy to get locally produced foods in the summer (mean $=4.2$ ) but not as easy in the winter $($ mean $=2.3)$. They also felt only moderate control over having a choice as to whether the foods they buy are locally grown (mean $=2.9$ ) and knowing whether the food they buy is locally grown $($ mean $=2.8)$.

\section{Attitudes toward promoting locally produced food}

Respondents strongly agreed with the idea that government should promote the buying of locally grown food (mean $=4.6)$ and also indicated that they would likely buy more locally produced foods if they were clearly marked with a logo in both grocery stores $($ mean $=4.3)$ and in restaurants $($ mean $=4.2)($ table 5).

\section{Breakdown of Findings by \\ Demographic Characteristics}

In addition to the overall analyses, all items were examined by sex, income, age, education level, and community size. There were not any meaningful differences on items for sex, income, education level and community size (data not presented). However, there was a tendency suggesting that increased age was associated with more favorable beliefs and attitudes toward locally produced food. Most notably, both the degree to which whether a product was local influenced the food purchasing decision and the propensity to buy local index increased with age (table 6).

\section{Relationship Between Beliefs, Ability, and Propensity to Buy Locally Produced Food} Using a multiple linear regression approach, a prediction model was created by regressing the belief and ability items on the propensity to buy local index. To determine whether beliefs or perceived ability to obtain locally produced food were stronger predictors, the four belief items were entered as a block followed by the four ability items. The same process was then reversed, entering the ability items first. As a block, the four beliefs items were a stronger predictor of the propensity to buy locally produced food $\left(\mathrm{R}^{2}=.25\right)$ than were the ability items $\left(\mathrm{R}^{2}=.13\right)$. Therefore, in the prediction model, the belief items were entered first, followed by the ability items. The four belief items explained 25 percent of the variance in propensity to purchase locally produced food. 
Adding the four ability items explained an additional 6 percent, resulting in 31 percent of the propensity to buy locally produced food explained by the eight belief and ability items. Examining the final model (table 7), after adjusting for all other variables, three belief items and one ability item were the strongest predictors of the propensity to buy local. The three belief items were "buying locally produced food is good for the local economy" $(B=.21)$, "buying locally produced food helps the environment" $(B=.20)$, and "local food is fresher than food produced farther away" $(B=.15)$. The ability item was "it is easy to get locally produced foods in the summer" $(B=.19)$.

\section{Discussion}

This study provided an opportunity to better understand the factors that influence people to buy local food, as well as the barriers they perceive to doing so. The sample of over 2,300 Nova Scotians was drawn primarily from individuals attending events oriented toward local agriculture or opportunities to buy local food. The overall results of the Buy Local Survey confirmed the expectation that patrons of agricultural fairs and farmers' markets hold positive beliefs and attitudes toward locally produced food and have a strong propensity to buy local. It is important to emphasize that the outcome of the survey reflects the beliefs and attitudes of a particular segment of the population and must be interpreted in this light. Specifically, the survey results are based on individuals who were willing and able to visit an agricultural fair or farmers' market. Thus, their reasons for buying local as well as their ability to do so may differ from that of the general public.

There was high agreement among survey respondents that food produced in Nova Scotia is "local." Although Nova Scotia is a relatively small province, using this geopolitical definition means that Nova Scotians could perceive food produced more than 500 kilometers (310 miles) away still as being local. A question that remains unanswered is the degree to which using political boundaries to define local is influenced by the size of the geographic area. It is uncertain whether consumers in other, larger provinces would use their provincial boundaries to define local, or whether they would use smaller boundaries within the province (e.g., counties) or different definitions altogether. Other studies have indicated that the distance food has traveled (Chambers, et al., 2007), geopolitical boundaries (Darby, et al., 2008; Hunt, 2007), and even social relations and product quality (Selfa \& Qazi, 2005) are used by different consumers for defining whether or not they consider food to be local.

A geopolitical definition of "local" employing provincial boundaries has positive policy implications, in that the provincial government could effectively equate a "buy Nova Scotia" campaign with a buy

\section{Table 7. Regression of Beliefs and Ability to Buy Locally Produced Food on Propensity to Buy Local Index}

\begin{tabular}{|c|c|c|c|c|c|}
\hline & b & Std Error & $B$ & $\mathrm{t}$ & sig \\
\hline Constant & 2.07 & .41 & & 4.98 & $<.001$ \\
\hline $\begin{array}{l}\text { Buying locally produced food is good for the local } \\
\text { economy }\end{array}$ & .85 & .09 & .21 & 9.67 & $<.001$ \\
\hline Buying locally produced food helps the environment & .50 & .06 & .20 & 8.73 & $<.001$ \\
\hline $\begin{array}{l}\text { Buying locally produced food means more money goes to } \\
\text { the farmer }\end{array}$ & -.03 & .06 & -.01 & -0.58 & ns \\
\hline Local food is fresher than food produced farther away & .42 & .07 & .15 & 6.33 & $<.001$ \\
\hline I find it easy to get locally produced foods in the summer & .49 & .05 & .19 & 9.59 & $<.001$ \\
\hline I find it easy to get locally produced foods in the winter & .16 & .05 & .06 & 3.13 & .002 \\
\hline It is easy to know whether the food I buy is grown locally & .14 & .05 & .06 & 3.06 & .002 \\
\hline $\begin{array}{l}\text { I have little choice over whether or not the foods I buy are } \\
\text { locally grown }\end{array}$ & .04 & .04 & .02 & 1.10 & ns \\
\hline
\end{tabular}


local campaign, as they would be similarly perceived by the consumer. Most survey respondents reported that they would buy more local food if it were better labeled in stores and also indicated strong support for government-led buy-local initiatives. And indeed, since this survey was conducted, the provincial government has launched the "Select Nova Scotia" campaign to promote the identification and purchasing of locally grown food. Based on the results of the survey, one can reasonably expect that there would be support among many Nova Scotians for this type of campaign designed to remove one of the main barriers to buying local, that is, the inability to identify locally produced food.

Despite strong favorable beliefs and attitudes toward locally produced food and the propensity to buy local, respondents reported moderate to low levels of ability to obtain locally produced food. This was evidenced by respondents reporting difficulty attaining local food in the winter as well as difficulty identifying whether food is locally grown. Certainly, in Nova Scotia most grocery shopping is conducted in two large supermarket chains, but respondents only gave these chain stores middling ratings as sources of local food. Venues perceived to be high in local food content, that is, farmers' markets, small fruit and vegetable stands, and direct from the farm, tend to be only available in the summer and at limited times, and would not be able to provide the entire food requirements for a typical family. Other studies have pointed out that not only must local food be available, but that given today's busy lifestyles, it must also be convenient (Chambers, et al., 2007; Stephenson \& Lev, 2004). It extends beyond the scope of this research to determine whether respondents' perceptions of the sources of local food are indeed accurate, but it is important that people who want to purchase local food know where they can obtain it.

Similar to other studies, respondents to this survey indicated that they strongly believe that local food is fresher than food from farther away and that buying local food benefits both local farmers and the local economy. However, unlike other studies, respondents gave an equally favorable rating to the belief that buying local helps the environment, and this item was one of the strongest predictors of respondents' propensity to buy local. Past studies on buying local either did not include an environmental component (Chambers, et al., 2007; Stephenson \& Lev, 2004) or concern for the environment was given relatively low ratings by participants (Schneider \& Francis, 2005; Selfa \& Qazi, 2005). One can speculate that the heightened awareness of the contribution that food miles potentially make to global warming is entering into food purchasing decisions. Consumers may be moving from considering buying local as solely a pragmatic issue of getting fresher food and supporting local economies, to encompassing larger sociopolitical issues where impacts can be made through responsible consumerism (Jacobsen \& Dulsrud, 2007; Vermeir \& Verbeke, 2006).

\section{Conclusion}

Environmental concerns, food-safety scares, and a general and growing distrust of the food system have contributed to consumers exploring potential alternatives to the agro-industrial model. The resurgence of a "buy local" ethos represents one such alternative. As the buy local movement grows, it becomes increasingly important to identify and understand the motivations of consumers most likely to be on the forefront as the movement becomes more mainstream. With this in mind, the current study focused on consumers from farmers' markets and agricultural fairs in the belief that many of them would likely try to regularly incorporate local foods into their everyday shopping. Using this approach helped provide insight into why people want to buy local food, as well as potential barriers that prevent stronger markets for local food products.

The results of this survey paint a picture of a group of consumers willing and eager to support buying local food, but feeling limited in their ability to do so. Perceptions of the main grocery-shopping venues as being mediocre sources of local food, the inability to discern whether or not food is local, and the perception that locally produced food is primarily available in the summer helps to account 
for consumers' overall beliefs that they have limited choice about purchasing local food. It is not surprising, therefore, that respondents also indicated strong support for the promotion of locally produced food, and in particular, labeling food as local. Unlike other studies that seem to indicate buy local campaigns need to convince people to purchase local food, the results of this survey suggest that for individuals who may already be oriented toward buying local food, the largest barriers are related to lack of information and supply. That is, locally grown food needs to be clearly identified and made more available to consumers in places where they would normally shop, increasing its convenience to shoppers. If given the information and opportunity to buy a local food product, it would indeed appear that many Nova Scotians would consciously do so. Further research using a broader sampling frame would be beneficial to determine whether these findings and conclusions are specific to the sample in this study or whether they extend to the general public.

Recent policy initiatives and buy local campaigns seem to suggest an underlying belief that many consumers are indeed prepared to buy local food if presented the opportunity (easily) to do so. For example, recent buy local campaigns in Nova Scotia have been largely oriented to raising awareness of the advantages of buying local and to increasing availability and ease of purchase. The current research was part of the Women's Institutes of Nova Scotia's Buy Local Challenge, a grassroots campaign to educate and encourage Nova Scotians to buy and advocate for local food. This campaign was likely one of the driving forces behind the Nova Scotia Provincial Government launching the Select Nova Scotia Campaign in 2007. The Select Nova Scotia Campaign reflects the survey results in that it focuses primarily on the availability and labeling of local foods and the benefits to both the consumer and producer of buying within the province. A provincial campaign along similar lines in Ontario has been used to help consumers more easily recognize fruits and vegetables produced in Ontario and to encourage consumers to support Ontario farmers by pur- chasing local produce. It would appear then that both policy-makers and food retailers recognize that there is a growing segment of the population oriented toward buying local food. Our survey results closely match this orientation and suggest that removing barriers to buying local, particularly through increasing availability and the ability to recognize local foods in retail outlets, is a critical component to meeting the demands of this growing segment of the population wanting to buy local.

\section{Acknowledgements}

The authors would like to acknowledge the Women's Institutes of Nova Scotia for their tremendous work administering the surveys and to all respondents who took the time to complete a survey. Thank you to Dr. Greg Cameron, Professor Lauranne Sanderson, and Dr. Deborah Stiles for reviewing earlier drafts of the manuscript.

\section{References}

Chambers, S., Lobb, A., Butler, L., Harvey, K., \& Traill, W. B. (2007). Local, national and imported foods: A qualitative study. Appetite, 49(1), 208-213. doi:10.1016/j.appet.2007.02.003

Darby, K., Batte, M. T., Ernst, S., \& Roe, B. (2008). Decomposing local: A conjoint analysis of locally produced foods. American Journal of Agricultural Economics, 90(2), 476-486. doi:10.1111/j.1467$\underline{8276.2007 .01111 . \mathrm{x}}$

de Jonge, J., van Trijp, H. C. M., Renes, R. J., \& Frewer, L. (2007). Understanding consumer confidence in the safety of food: Its two-dimensional structure and determinants. Risk. Analysis, 27(3), 729-740. doi:10.1111/j.1539-6924.2007.00917.x

de Jonge, J., van Trijp, J. C. M., van der Lans, I. A., Renes, R. J., \& Frewer, L. J. (2008). How trust in institutions and organizations builds general consumer confidence in the safety of food: A decomposition of effects. Appetite, 51(2), 311-317. doi:10.1016/j.appet.2008.03.008

de Jonge, J., van Trijp, H., Goddard, E., \& Frewer, L. (2008). Consumer confidence in the safety of food in Canada and the Netherlands: The validation of a generic framework. Food Quality and Preference, 19(5), 439-451. doi:10.1016/i.foodqual.2008.01.002

Eden, S., Bear, C., \& Walker, G. (2008). Understanding and (dis)trusting food assurance schemes: Consumer confidence and the "knowledge fix." Journal of Rural Studies, 24(1), 1-14. doi:10.1016/j.jrurstud.2007.06.001 
Exhibition Association of Nova Scotia. Retrieved from http://www.eans.ca/index.html

Guthman, J. (2004). Agrarian dreams: The paradox of organic farming in California. Berkeley: University of California Press.

Hinrichs, C. C. (2000). Embeddedness and local food systems: Notes on two types of direct agricultural market. Journal of Rural Studies, 16(3), 295-303. doi:10.1016/S0743-0167(99)00063-7

Hunt, A. R. (2007). Consumer interactions and influences on farmers' market vendors. Renewable Agriculture and Food Systems, 22(1), 54-66. doi:10.1017/S1742170507001597

Jacobsen, E., \& Dulsrud, A. (2007). Will consumers save the world? The framing of political consumerism. Journal of Agricultural and Environmental Ethics, 20(5), 469-482. doi:10.1007/s10806-007-9043-z

Kloppenberg, J., Lezberg, S., DeMaster, K., Stevenson, G. W., \& Hendrickson, J. (2000). Tasting food, tasting sustainability: Defining the attributes of an alternative food system with competent, ordinary people. Human Organization, 59(2), 177-186.

Michael, G. (2008, March). Strategic directions for Farmers' Markets of Nova Scotia Cooperative Ltd. Labour Market Development Program. Halifax, Nova Scotia: FMNS Labour Market Development Program.

Nicolosi, G. (2006). Biotechnologies, alimentary fears and the orthorexic society. Tailoring Biotechnologies, 2(3), 37-56.

Pollan, M. (2006). The omnivore's dilemma: A natural history of four meals. New York: Penguin Press.
Roininen, K., Arvola, A., \& Lähteenmäki, L. (2006). Exploring consumers' perceptions of local food with two different qualitative techniques: Laddering and word association. Food Quality and Preference, 17(1-2), 20-30. doi:10.1016/i.foodqual.2005.04.012

Schneider, M. L., \& Francis, C. A. (2005). Marketing locally produced foods: Consumer and farmer opinions in Washington County, Nebraska. Renewable Agriculture and Food Systems, 20(4), 252260. doi:10.1079/RAF2005114

Selfa, T., \& Qazi, J. (2005). Place, taste, or face-to-face? Understanding producer-consumer networks in "local" food systems in Washington State. Agriculture and Human Values, 22(4), 451-464. doi:10.1007/s10460-005-3401-0

Smithers, J., LaMarche, J., \& Joseph, A. (2008). Unpacking the terms of engagement with local food at the farmers' market: Insights from Ontario. Journal of Rural Studies, 24(3), 337-350. doi:10.1016/j.jrurstud.2007.12.009

Stephenson, G., \& Lev, L. (2004). Common support for local agriculture in two contrasting Oregon communities. Renewable Agriculture and Food Systems, 19(4), 210-217.

Vermeir, I., \& Verbeke, W. (2006). Sustainable food consumption: Exploring the consumer "attitudebehavioral intention" gap. Journal of Agricultural and Environmental Ethics, 19(2), 169-194. doi:10.1007/s10806-005-5485-3 
Journal of Agriculture, Food Systems, and Community Development ISSN: 2152-0801 online www.AgDevJournal.com 